\title{
Initialism hypothesis: can gibberellin synthesis inhibitor increase the oat crop competitive ability?
}

\author{
Marcus Vinícius Fipke ${ }^{1}$, Ribas Antonio Vidal'1, Marcelo Teixeira Pacheco ${ }^{1}$, Luiz Carlos Federizzi ${ }^{1}$ \\ 1 Universidade Federal do Rio Grande do Sul, Faculdade de Agronomia, Departamento de Plantas de Lavoura, Porto Alegre, RS, Brasil. E-mail: marfipke@gmail.com (ORCID: \\ 0000-0002-3057-9522); ribas.vidal@gmail.com (ORCID: 0000-0002-6186-4713); marpac@ufrgs.br (ORCID: 0000-0001-5147-7448); federizi@ufrgs.br (ORCID: 0000-0003- \\ 3954-2766)
}

ABSTRACT: The initialism hypothesis proposes that gibberellin is involved in the cascade of events triggering the impact of weeds very early on the crop plant development. The objectives of this research were to demonstrate differences in competitive ability of two oat (Avena sativa) cultivars and to test the hypothesis that gibberellin inhibitors may increase the oat crop grain yield under limited Italian ryegrass (Lolium multiflorum) weed density. Two substitutive series experiments were conducted in a greenhouse to evaluate two oat cultivars (URS Brava (tall height) and URS Taura (short height)) in coexistence with Italian ryegrass. Additionally, two field additive-type experiments were conducted using a factorial arrangement of treatments with oat cultivar URS Brava and other URS Taura. The first factor consisted of gibberellin inhibitor (trinexapac-ethyl at 0 and $37.5 \mathrm{~mL} \mathrm{ha}^{-1}$ ) and the second factor was the density of Italian ryegrass (ranging from 0 to 21 plants $\mathrm{m}^{-2}$ ). The substitutive series experiment evidenced that the competitive ability of oat plants is superior to Italian ryegrass plants. The gibberellin-treated 'Brava' oat crop grain yield increased at small ryegrass densities. This is the first experimental evidence that the gibberellin inhibitor can avoid crop grain yield losses caused by weeds.

\section{Hipótese do inicialismo: o inibidor da síntese de giberelina pode aumentar a habilidade competitiva da aveia?}

RESUMO: A hipótese do inicialismo propõe que a giberelina esteja envolvida na cascata de eventos que desencadeia o impacto de plantas daninhas no desenvolvimento inicial da cultura. Os objetivos desta pesquisa foram demonstrar as diferenças na capacidade competitiva de dois cultivares de aveia e para testar a hipótese de que inibidores de giberelina podem aumentar 0 rendimento de grãos de aveia sob limitada densidade de plantas daninhas de azevém (Lolium multiflorum). Dois experimentos de séries substitutivas foram conduzidos em casa de vegetação para avaliar duas cultivares de aveia (URS Brava (alta estatura) e URS Taura (baixa estatura)) em convivência com azevém. Adicionalmente, dois experimentos de campo do tipo série aditiva foram conduzidos utilizando arranjo de tratamentos fatorial com as cultivares URS Brava e outro com URS Taura. O primeiro fator consistiu de níveis de inibidor de giberelina (trinexapac-ehtyl no 0 e $37,5 \mathrm{~mL} \mathrm{ha}^{-1}$ ) e o segundo fator foi a densidade de azevém (variando de 0 a 21 plantas $\mathrm{m}^{-2}$ ). No experimento de série substitutiva evidenciou-se que a capacidade competitiva das plantas de aveia é superior às de azevém. Produção de grãos de aveia 'Brava' tratada com giberelina aumentou em densidades de azevém. Esta é a primeira evidência experimental de que o inibidor de giberelina pode evitar perdas no rendimento de grãos causados por plantas daninhas.

Palavras-chave: Avena sativa; produtividade da cultura; processos dependente-densidade; Lolium multiflorum 


\section{Introduction}

A cultural method of weed control consists of, among other management tactics, the choice of crop cultivars with attributes that provide a competitive advantage against the weeds. The plant height is listed as one of the main crop characteristics for high competitiveness (Trezzi et al., 2013; Worthington et al., 2015). However, the knowledge of the mechanisms of crop-weed interaction indicates that physiological characteristics are the driving cause on competitive ability (Vidal et al., 2012; McKenzie-Gopsill et al., 2016). Indeed, the presence of neighboring plants decreases the ratio of red to far-red (R:FR) light, triggering a complex cascade of events, which leads to morphological changes in plants (altering shoot:root ratio). This phenomenon is called "shade avoidance syndrome" (McKenzie-Gopsill et al., 2016), but the term initialism has been proposed (Vidal et al., 2012), because no shade is needed to trigger the response ( $G a l$ et al., 2015).

The quality of light can affect crops and weeds differently (Casal \& Smith, 1988). The decrease in the branching, tillering and aboveground biomass part due to the elongation caused by the decrease of the R:Fr ratio tends to be more harmful to the crops than the weeds. The induction of the elongation in early stages of the plant is correlated with the decrease of the plasticity in late stages of development (Weining \& Delph, 2001). In crops, the initial developmental is directly related to the development of grains. Being the crops with high productive potential the most affected. In weeds, the damage caused by the decrease in light quality can be compensated for by its high plasticity, not compromising future competition (Weining \& Delph, 2001; McKenzie-Gopsill et al., 2016).

Gibberellin is reported to be involved in the cascade of biochemical events which increase the shoot height and aboveground mass, decreasing the root system (Wit et al., 2016). Gibberellin inhibitors may avoid the imbalance on the shoot:root ratio, thus avoiding the loss of the plant competitive ability (Vidal et al., 2012). In oat plants, there are studies with trinexapac-ethyl (gibberellin inhibitor), but the spray in the tillering, with objective to reduce height (Hawerroth et al., 2015). When using trinexapac-ethyl in oats at two stages (first and second visible node) there was a reduction of plant height in relation to plants without application (Hawerroth et al., 2015). So far, no experimental evidence has shown that gibberellin-mediated mechanism can affect crop grain yield. However, it is hypothesized that reduced phenotypic plasticity in traits such as initialism (shade avoidance syndrome) may increase competitive ability and increase crop grain yield.

In weed science, the classical method to evaluate the impact of the weeds on the crop grain yield is the additive experiment design, where the weed density varies and the crop density is held constant (Portugal \& Vidal, 2009). In this type of experiment, the total plant population is not constant for all treatments. In contrast, the substitutivetype experiment (also called replacement series) maintains the total plant density constant, whereas the proportions of two competing species vary in each treatment. The yield (of the variable being analyzed) of the mixtures is compared to the yield of the monocrop of each species. This last method is most valuable in assessing the competitive effects of two species at a single total density and determining the relative degrees of intra- and interspecific interference (Lamego et al., 2011). The cultivated oat is one of the most competitive crop species (Schaedler et al., 2009), whereas the Italian ryegrass (hereon called 'ryegrass') is an important weed for winter crops in South American.

The oat and ryegrass were used as models with two objectives. First, to use a replacement series experiment to evaluate differences in competitive ability of two oat cultivars in relation to ryegrass. Second, to use the method of additive experiments to test the hypothesis that gibberellin inhibitors may reducing the effects of initialism and increase the oat crop grain yield under weed density, using oat cultivars with different competitive abilities.

\section{Materials and Methods}

\section{Greenhouse studies}

Two greenhouse experiments were conducted in mayseptember 2015 at the Federal University of Rio Grande do Sul (UFRGS) in Porto Alegre, Brazil. Day and night temperatures

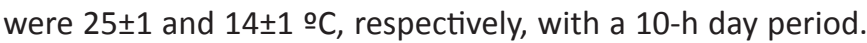
In both experiments was used the soil Dystrophic Red-Dark Argisoil, clay-loamy texture with $34 \%$ clay, $\mathrm{pH}(5,6)$, calcium

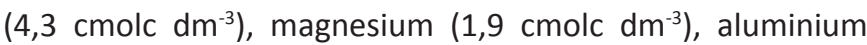
$\left(0 \mathrm{cmolc}^{-3}\right)$, phosphorus $\left(20 \mathrm{mg} \mathrm{dm}^{-3}\right)$, potassium (165

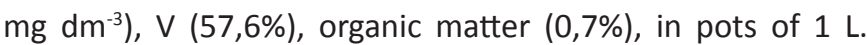
Recommended fertilization was used for the cultivation of oats (Lângaro et al., 2014). The first experiment, with the monocrop oat and ryegrass (separately), aimed to determine a population of plants $\mathrm{m}^{-2}$ from which shoot dry mass per unit area $\left(\mathrm{g} \mathrm{m}^{-2}\right)$ becomes independent of the population, according to a "constant final production law" (Radosevich et al., 2007). The populations established for testing were 0,1 , $2,4,6,8,10,12$ and 14 plants per pot $(1000 \mathrm{~mL})$ for oat and ryegrass (individual experiments). The experimental design was completely randomized, with seven replications each experiment. At thirty days after emergence (DAE) was collect the plants were cut at the soil surface, oven dried for $168 \mathrm{~h}$ at $60 \stackrel{\circ}{ } \mathrm{C}$ and their mass determined per plant analyzed in each experimental.

In the second experiment, it was used two oat cultivars: URS Brava (tall stems, short life cycle) and URS Taura (short stems, short life cycle). The experimental units were arranged in a randomized complete block design with four replicates. According to the results obtained in the first experiment, 7 and 14 plants per pot for both oat cultivar and Italian ryegrass were defined as maximum densities, respectively. The oat:ryegrass proportions (plants/pot) were 7:0 (pure oat stand), 6:2, 5:4, 4:6, 3:8, 2:10, 1:12, 0:14 (pure ryegrass stand), which corresponded to the following percentages of oat:ryegrass proportion, respectively, 100/0; 86/14; 71/29; 
$57 / 43 ; 43 / 57 ; 29 / 71 ; 14 / 86$ and $0 / 100$. Thirty DAE, the plants were cut at the soil surface, oven dried for $168 \mathrm{~h}$ at $60 \stackrel{\circ}{ } \mathrm{C}$ and their mass determined per plant. Competitiveness of the species was evaluated based on the relative yield (RY) of aboveground dry mass (shoots), as shown in Equation 1:

$$
\mathrm{RY}=\frac{\mathrm{wmix}}{\mathrm{wmon}}
$$

where $R Y$ is the ratio between the weight of the species in the mixture (wmix) and the weight of the species in monoculture (wmon). Relative yield total (RYT) is the total RY of the two associated species, as shown in Equation 2:

$$
\mathrm{RYT}=\mathrm{RYspecie} \mathrm{A}+\mathrm{RYspecie} \mathrm{B}
$$

\section{Field experiments}

Two field experiments were conducted at the Experimental Research Station of UFRGS, located in Eldorado do Sul, Brazil $\left(30^{\circ} 4^{\prime} 30^{\prime \prime} \mathrm{S}\right.$ and $\left.51^{\circ} 39^{\prime} 18^{\prime \prime} \mathrm{W}\right)$, during July to November/2015. The soil at the experimental site has a sandy clay loam texture (Acrisol), with characteristics $27 \%$ clay, $\mathrm{pH}(5,6)$, calcium $(4,3$ cmolc $\left.\mathrm{dm}^{-3}\right)$, magnesium $\left(1,9 \mathrm{cmolc}^{-3}\right)$, aluminium $(0 \mathrm{cmolc}$ $\left.\mathrm{dm}^{-3}\right)$, phosphorus $\left(20 \mathrm{mg} \mathrm{dm}^{-3}\right)$, potassium (165 mg dm $\mathrm{m}^{-3}$ ), base saturation $(71,0 \%)$, organic matter $\left(21 \mathrm{~g} \mathrm{~kg}^{-1}\right)$. During the field experiments, the average daily air temperature ranged from 14.9 to $23.3^{\circ} \mathrm{C}$; whereas the total rainfall was $993 \mathrm{~mm}$ (Table 1).

The experimental design was a randomized block and the treatments were organized in a factorial arrangement with four replicates. Each experiment consisted of 56 plots. Each experimental unit had dimensions of $1.0 \mathrm{~m} \times 5.0 \mathrm{~m}$ ( 5 oat lines spaced $0.20 \mathrm{~m}$ ), totaling an area of $5.0 \mathrm{~m}^{2}$. In one experiment the oat cultivar (cv.) used was URS Brava, whereas the other had the URS Taura cv. On each experiment, the first factor consisted of gibberellin inhibitor (GI) treatments ( 0 and 37.5 $\mathrm{mL} \mathrm{ha}^{-1}$ of trinexapac-ethyl (Moddus, $250 \mathrm{~g}$ a.i. $\mathrm{L}^{-1}$, Syngenta) and the second factor was the density of the ryegrass plants $\left(0,1,3 ; 6,9,15\right.$ and 21 plants $\left.\mathrm{m}^{-2}\right)$.

The experiments followed the same procedures unless otherwise stated, which were cultivated under no-tillage cropping systems during the past 10 years. Starter fertilizer use was based on the soil analysis and consisted of $300 \mathrm{~kg} \mathrm{ha}^{-1}$ of the formulation 0-20-20 ( $\left.\mathrm{N}-\mathrm{P}_{2} \mathrm{O}_{5}-\mathrm{K}_{2} \mathrm{O}\right)$ and was distributed on the soil across the crop rows. Top dressing nitrogen

Table 1. Relation of month averages of temperature minimum (Min.), maximum (Max.) and precipitation temperatures during the 2015 harvest.

\begin{tabular}{lccc}
\hline \multirow{2}{*}{ Month } & \multicolumn{2}{c}{ Temperature $\left({ }^{\circ} \mathrm{C}\right)$} & $\begin{array}{c}\text { Precipitation } \\
(\mathbf{m m})\end{array}$ \\
\cline { 2 - 3 } & Min. & Max. & 309.2 \\
\hline July & 12.7 & 20.2 & 108.9 \\
August & 16.2 & 26.2 & 184.0 \\
September & 13.8 & 22.1 & 307.3 \\
October & 15.4 & 23.6 & 83.3 \\
\hline November & 17.6 & 25.2 & \\
\hline
\end{tabular}

fertilizer at $34 \mathrm{~kg} \mathrm{ha}^{-1}$ (urea) was applied twice when the oat crop plants were at the growth stage 23 and 27 (BBCH-cereal scale, Lancashire et al., 1991).

The weed (ryegrass) seeds were harvested the previous year in fields adjacent to the experimental areas. The weed seeds were counted according the desired density and mixed with the crop seeds for mechanical sowing with a seed drill. The oat crop was sown at the density of 350 seeds $\mathrm{m}^{-2}$. The emergence of oat plants occurred around two weeks after sowing, and the ryegrass plants were around three to four weeks. Plant density was determined four weeks after emergence. The excess of ryegrass plants were removed to adjust to the desired plant density per treatment

Crop diseases were controlled at 28, 43, 63 and 76 days after the plant emergence (DAE), using $150 \mathrm{~g} \mathrm{ha}^{-1}$ of tebuconazole (Tebuconazole, Nortox, $200 \mathrm{~g} \mathrm{t}^{-1}$ of a.i.). Insect control was done at 28 and $43 \mathrm{DAE}$, using $250 \mathrm{~g} \mathrm{ha}^{-1}$ of dimetoato (Dimetoato, Nortox, $500 \mathrm{~g} \mathrm{~L}^{-1}$ of a.i.). The gibberellin inhibitor trinexapac-ethyl was sprayed at $6 \mathrm{DAE}$, according to the treatments. The non-ionic surfactant nonyl phenol ethylene oxide (Agral, Syngenta, $200 \mathrm{~g} \mathrm{~L}^{-1}$ of a.i.), at 0.2 $\%(v: v)$ was added to all pesticides. All pesticides were applied with a back-pack sprayer, pressurized with $\mathrm{CO}_{2}$, at $200 \mathrm{kPa}$, with a boom containing nozzles type $110.02 \mathrm{XR}$, calibrated to deliver a volume equivalent to $160 \mathrm{~L} \mathrm{ha}^{-1}$. The oat plants height was evaluated at 7 weeks after emergence. The crops were harvested when the plants presented uniform maturity to assess grain yield, with harvester of grains was carried out in an area of $5 \mathrm{~m}^{2}$ plot $^{-1}$, yielding the crop yield by weighing the grains in the husk and with humidity adjusted to $13 \%$.

\section{Statistical analysis}

For greenhouse studies, statistical analysis were performed using SAS software (SAS Institute Inc., Cary, North Carolina, USA). The relative productivity graphical analysis method was use, considering the treatment mean and the standard error of the mean (Radosevich et al., 2007). A RYT of 1 indicates that species $A$ and $B$ are demanding on the same limiting resources. If RYT is $<1$ it indicates that there is an antagonism between species $A$ and $B$. The relative competitivity index $(R C)$, the relative grouping coefficient (K) for each plant species and the competitivity index (A) were calculated at the $50 \%$ proportion of plants from each competing species. These indexes were calculated based on equations by Cousens \& O'Neill (1993). These models described the possible outcomes of the interaction of two species when grown in a replacement series arrangement (Radosevich et al., 2007). RC represents the relative growth of one plant species compared to its competitor; $\mathrm{K}$ indicates the relative dominance of one species over another, and A indicates which species is more competitive. The joint interpretation of these values indicates the competitiveness degree of the species involved. The oat plants would be more competitive than the ryegrass when RC $>1$; Koat $>$ Kryegrass; and $A>0$. Ryegrass plants would be more competitive than oats when $\mathrm{RC}<1$; Koat $<$ Kryegrass and $\mathrm{A}<0$ (adapted from Hoffman \& Buhler, 2002). The test $t$ was used 
to evaluate the differences in the indices studied in relation to the hypothetical line (Hoffman \& Buhler, 2002). The null hypotheses used to test the differences of PR and A were that they were equal to zero $(\mathrm{HO}=1)$; for $\mathrm{PRT}$ and $\mathrm{CR}$, the means would be equal to $1(\mathrm{HO}=1)$; And for index $\mathrm{K}$, that the means of the differences between Koat and Kryegrass were equal to zero $[\mathrm{HO}=($ Koat-Kryegrass $)=0]$.

For field experiments, statistical analysis were performed using SAS software (SAS Institute Inc., Cary, North Carolina, USA). Prior to the analysis of variance, height data collected from the experiments were transformed to percentage in relation to the weed-free control. For the data that there was interaction by analysis of variance between the doses of gibberellin inhibitor and density of the ryegrass (obtained from an F-test, $p \leq 0.05$ ), the regression analysis between the weed density and the dependent variables was conducted, adjusting linear and nonlinear models to each treatment average. For plant height in both experiments, the models were based on linear regression. In experiment with URS Brava, for oat grain yield the models were quadratic equations. For experiment URS Taura there was no significant interaction between the evaluated factors, but there was interaction for the ryegrass density. Therefore, in the regression analysis of this variable, the mean of the gibberellin inhibitor dose factor was used, adjusting the exponential equation of three parameters. It was calculated the standard error of the estimative of the treatment mean.

\section{Results and Discussion}

\section{Greenhouse studies}

For both oat cultivars, depending on the oat:ryegrass proportion tested, there were differences in the competitive abilities between oats and ryegrass (Figure 1). The plant proportion on each treatment was based on preliminary experiments which shown that each oat plant were equivalent to two ryegrass plants (data not shown). For the experiment with oat cultivar Taura, the RYT > 1 for two oat:ryegrass plant proportions (86:14 and 29:71) indicates that either the plants of the two species are not competing or that one specie is capturing more resources than the other is losing. Overall, plants from the oat cultivar Taura were more competitive than ryegrass plants (Figure 1a). For this cultivar, on four plant proportion $(86: 14,57: 43,43: 57,29: 71)$ the RY were above than the dashed line (hypothetical no interaction line), indicating the oat plants probably are benefiting from the interaction with ryegrass. On the other hand, ryegrass plants presented RY below to the dashed line on four oat:ryegrass plant proportions $(86: 14,71: 29,57: 43,43: 57)$, indicating the plants from this species are negatively affected by the competition with URS Taura (Figure 1a).

In the experiment with oat cultivar Brava, the RYT was $<1$ (Figure 1b). RYT below to 1 (corresponding to a concave line) suggests that the two plant species are competing for the same resources and one or both are negatively affected by this competition (Radosevich et al., 2007). The RY for ryegrass

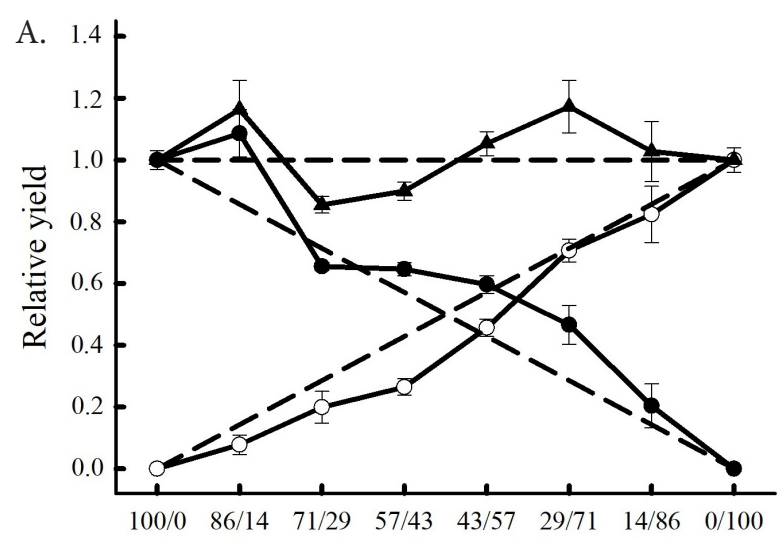

Proportion of plants oat / ryegrass

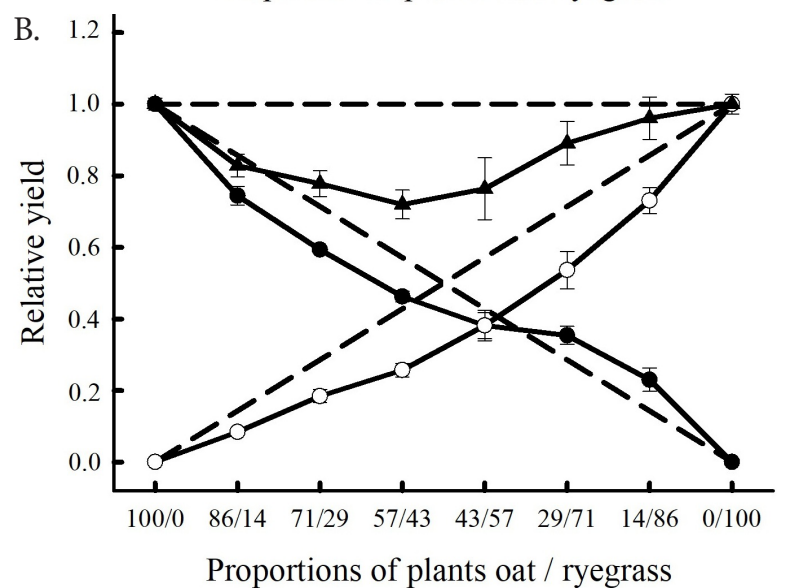

Dashed lines represent the hypothetical relative yield when there is no interference of one species over another.

Figure 1. Relative yield and yield total for dry mass of shoots of ryegrass and oat crop cv. URS Taura (a) and cv. URS Brava (b), depending on the proportion of plants from (•) oat crop (o) ryegrass and ( $\boldsymbol{\Delta}$ ) RYT.

plants was below the dashed line in all the associations with the oat plants, indicating that this species was negatively affected by the coexistence with oat plants. Likewise, the RY for the oat plants was below to the dashed line when the proportion of the oat plants in the pot was between 57 and $86 \%$ (Figure $1 \mathrm{~b}$ ).

The greenhouse experiments have demonstrated that plants of both crop cultivars were more competitive that the Italian ryegrass plants. Overall, the replacement series experiments demonstrated that plants from the cultivar Taura were more competitive against ryegrass plants than the cultivar Brava (Figure 1). The oat plants utilized the resources more efficiently than the ryegrass plants. This result are in accordance with the ones reported in the literature prove that winter crops such as oat (Almeida \& Mundstock, 2001), wheat (Rigoli et al., 2009) and barley (Wanic et al., 2013) are more competitive than ryegrass plants.

For both oat cultivars, all competitiveness indexes calculated were significant. Indeed, both cultivars presented $\mathrm{RC}>1 ; \mathrm{K}_{\text {oat }}>\mathrm{K}_{\text {ryegrass }}$; and $\mathrm{A}>0$; indicating that the oat plants were more competitive than the ryegrass plants. All the competitive indexes calculated for the cultivar Taura were superior to the ones calculated for cultivar Brava (Table 2). 
Table 2. Competitive index between oat plants (cV. URS Taura e URS Brava) and ryegrass plants, expressed by relative competitiveness $(\mathrm{RC})$, clusterings relative coefficients $(K)$ and competitiveness $(A)$ at $30 \mathrm{DAE}$.

\begin{tabular}{|c|c|c|c|c|c|}
\hline & & RC & $\mathrm{K}_{\text {oat }}$ & $K_{\text {rygress }}$ & $\mathrm{A}$ \\
\hline Taura $^{1}$ & Shoot dry mass & $1.81(0.15)^{*}$ & $1.68(0.16)^{*}$ & $0.70(0.06)^{*}$ & $0.27(0.04)^{*}$ \\
\hline Brava & Shoot dry mass & $1.50(0.17)^{*}$ & $0.85(0.01)^{*}$ & $0.59(0.09)^{*}$ & $0.14(0.03)^{*}$ \\
\hline
\end{tabular}

${ }^{1}$ Taura $=$ cultivar URS Taura; and Brava= cultivar URS Brava.

* indicates significance of the index by the " $\mathrm{t}$ " test $(\mathrm{P}<0.05)$. Values in parentheses represent the standard error of the mean and are used to compare data from both cultivars.

The competitive indexes from Table 1 show that the oat cultivar with short plants (Taura) was more competitive with ryegrass than the one with tall plants (Brava). A possible interpretation of the results may be due to the time of competition between the species, where the initial rapid growth may have favored the URS Taura. The competitive ability of plants is a function of several crop traits, including fast initial growth, high tillering and prominent root systems (Liebman et al., 2016). Crop plant size can provide increase competitive ability by reducing access to light (Almeida \& Mundstock, 2001; Liebman et al., 2016), but this characteristic is not pursued in crop breeding of new cultivars (Borlaug, 2007). Physiological characteristics are involved in, also, on plant competitive ability (Vidal et al., 2012; McKenzie-Gopsill et al., 2016). It is interesting to note that the semi-dwarf wheat plants precursors of the gene revolution contain $R h t$ genes, which are involved in with sensitivity/response to gibberellin (Lou et al., 2016). In case of oat crop, dwarfism is not associated to Rht genes, but to $D w$ gene family (Milach et al., 2002). We are unaware of any data from the literature that demonstrates the association of gibberellin inhibitors and the weed competitive ability in either wheat or oat crop.

In the greenhouse experiment the objective was to evaluate the competitive ability of two oat cultivars in relation to ryegrass in the initial stages of growth. It was demonstrated that oat cultivars were more competitive than ryegrass during the first 30 days of competition and that the low-growing cultivar showed higher competitiveness indices in relation to the high-growing cultivar. From this, experiments were carried out in the field to evaluate whether inhibitor of gibberellin, when applied very early in the plant life cycle, can maintain the crop competitive ability without there being a decrease in grain yield.

\section{Field experiment with the oat cultivar URS Brava}

In the variable plant height, there was interaction $(p<0.20)$ between the factors ryegrass plant density and GI (Figure 2a). For treatment without GI inhibitor, the linear equation gave appropriate fit to the observed data. No differences on plant height were detected at low ryegrass plant densities (nine plants $\mathrm{m}^{-2}$ ). When IG inhibitor was used, the oat plant height was not affected by ryegrass density. But, in the absence of GI inhibitor, the line estimated for oat height decreased linearly with increasing ryegrass density probably caused by the effect of competition between crop and weed.

For oat grain yield, there was interaction $(p<0.15)$ between the factors ryegrass density and GI (Figure $2 b)$. Grain yield for treatments without ryegrass was 1735 and $1645 \mathrm{~kg} \mathrm{ha}^{-1}$ for
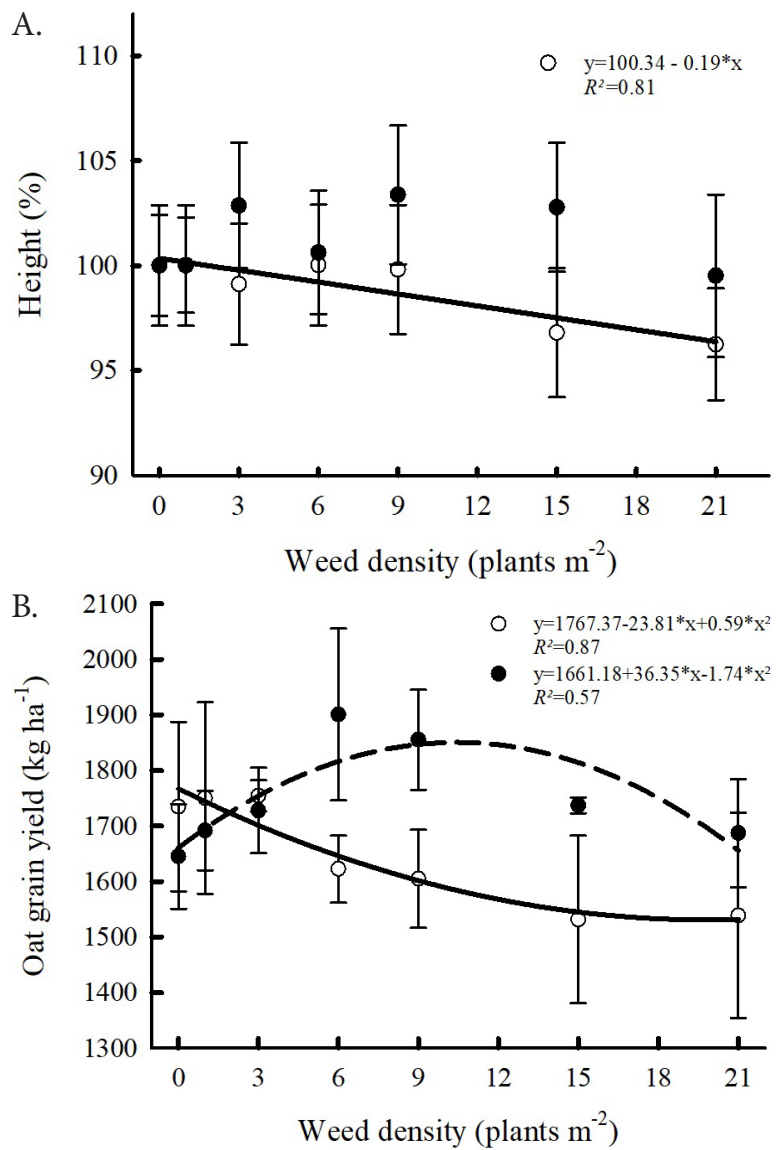

Height data are presented in \% in relation to weed-free control. Each dot represents the average of four repetitions. Bars represent the confidence intervals (95\%) of the estimative of the treatment mean. n.s. = non significant $(P>0.05)$.

Figure 2. Impact of ryegrass density and gibberellin inhibitor (GI) on the height of oat (URS Brava) at 35 days after plant emergence (a) and grain yield (b) of oat plants cv. URS Brava. (o) without $\mathrm{Gl}$ and $(\bullet)$ with $\mathrm{Gl}$.

treatments without and with $\mathrm{Gl}$, respectively. In the absence of $\mathrm{GI}$ inhibitor, the oat grain yield decreased to according with increase weedy ryegrass density. However, when gibberellin inhibitor was used, there was a quadratic impact of ryegrass density on oat grain yield. Thus, the crop grain yield increased proportionally for ryegrass density up to 9 plants $\mathrm{m}^{-2}$ and, at the highest density ( 21 plants $\mathrm{m}^{-2}$ ), the oat yield returned back to the same level of crop grain yield observed on the weedfree treatment (Figure $2 b$ ).

\section{Field experiment with the oat cultivar URS Taura}

For oat plant height, there was interaction $(p<0.20)$ between the factors ryegrass plant density and GA inhibitor (Figure 3a). Each Gl inhibitor level, the linear equations gave appropriate fit to the observed data. The oat plants height 

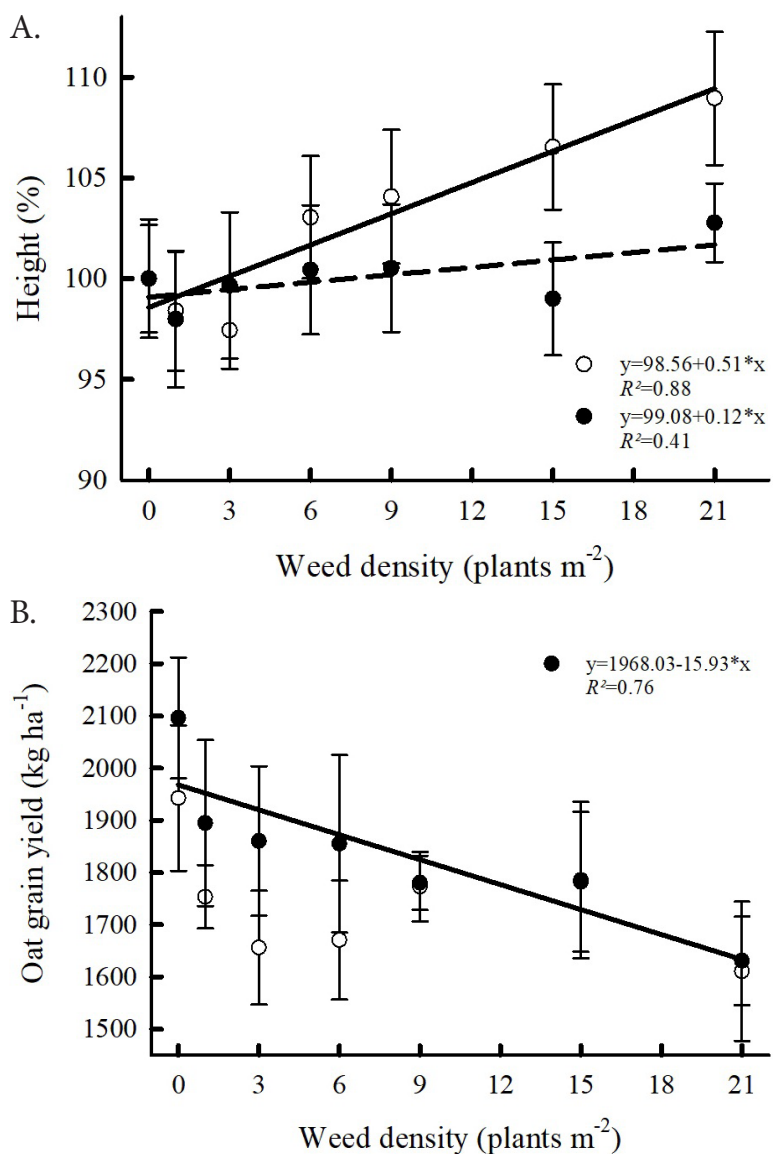

Height data are presented in \% in relation to weed-free control. Each dot represents the average of four repetitions. Bars represent the confidence intervals $(95 \%)$ of the estimative of the treatment mean. n.s. = non significant $(P>0.05)$.

Figure 3. Impact of ryegrass density and gibberellin inhibitor (GI) on the height of oat (URS Taura) at 35 days after plant emergence (a) and grain yield (b) of oat plants cv. URS Taura. (o) without $\mathrm{Gl}$ and $(\bullet)$ with $\mathrm{Gl}$.

increased was directly proportional to the ryegrass density. No differences on plant height were detected at low (up to nine plants $\mathrm{m}^{-2}$ ) ryegrass plant densities. However, at ryegrass densities of 15 and 21 plants $\mathrm{m}^{-2}$, the oat plants were taller without GI inhibitor than with GI inhibitor.

For oat grain yield, there was no interaction between the factors ryegrass plant density and gibberellin inhibitor (Figure $3 \mathrm{~b}$ ). In the plots without ryegrass, the yield of grains were 1943 and $2004 \mathrm{~kg} \mathrm{ha}^{-1}$ for the treatments without and with $\mathrm{Gl}$, respectively. Averaged for both GI levels, the oat grain yield decreased with the increment of ryegrass plants. Independently of the $\mathrm{Gl}$, the highest crop productivity was observed in the absence of weed. It is worth mentioning that when ryegrass density were between 1 and 6 plants $\mathrm{m}^{-2}$ the oat grain yield was superior on the treatments with $\mathrm{Gl}$ in comparison to treatments without $\mathrm{Gl}$. At the highest ryegrass density ( 21 plants $\mathrm{m}^{-2}$ ), the oat grain yield was $12 \%$ lower than the observed on weed-free treatments (Figure $3 \mathrm{~b}$ ), indicating this weed can cause substantial yield loss to this crop.

The results from the field experiments provided evidence for the hypothesis that gibberellin inhibitor can maintain the crop grain yield. Indeed, in all ryegrass densities ( $<21$ plants $\mathrm{m}^{-2}$ ) tested with the gibberellin-treatment applied on 'Brava' cultivar, the crop grain yield was equal or superior to the attained on the weed-free treatment (Figure 2b). However, when the gibberellin-treatment was applied on "Taura" cultivar, the crop grain yield was superior in the gibberellinuntreated only in some weed densities (Figure 3b). This research provides the first experimental evidence for the initialism hypothesis (Vidal et al., 2012), in which a gibberellinmediated mechanism can prevent yield loss at low weed densities.

The fact that gibberellin-treated 'Brava' oat crop grain yield increased at small ryegrass densities (e.g. 9 plants $\mathrm{m}^{-2}$ ) (Figure $2 \mathrm{~b}$ ) support the hypothesis that reduced phenotypic plasticity in initialism trait maintain competitive ability and increase crop grain yield (Weiner at al., 2010). Besides that, other ecological principles of positive interaction among plants from different species, such as facilitation, might be involved as well. The facilitation principle is based on at least four hypotheses. The "stress gradient hypothesis" proposes that different species offer protection against abiotic stresses (Lortie \& Callaway, 2006); whereas protection against biotic stresses are justified by the "trap crop hypothesis" (Poveda \& Kessler, 2012), or by the "push-pull hypothesis" (Hassanali, 2008), or by the "natural enemy hypothesis" (Hooksa et al. 2010). However, no other variables were evaluated in our field experiments to provide evidence for any of these hypotheses.

At least two conditions were considered when planning these experiments. First, the selection of a weed (Italian ryegrass) with limited competitive ability (Figure 1), probably due to low initial plant growth rate. Second, the choice of a (tall) crop cultivar responsive to gibberellin inhibitor. Considering these boundaries and assuming limited weed seed infestation in the soil, there are several applications of the results from this research. Gibberellin inhibitor might become a useful enhancer of crop competitive ability help to avoid yield losses due to weed competition. Also, it is possible to speculate that crop breeding could be used to minimize the initialism-type crop-weed interaction mechanism (Vidal et al., 2012). Elucidation of biochemical/genetic details of this weed-crop interaction mechanism might be useful to develop new approaches to integrated weed management. Also, we speculate that the levels of gibberellin or other genes/ proteins involved in the cascade of events associated with this competition mechanism might be used as an indicator of weed interference on the crop, and could help the decisionmaking regarding the weed management.

\section{Conclusion}

This research evidenced that: the competitive ability of the oat plants is superior than of Italian ryegrass plants; the competitive ability of the cultivated oat is dependent on the cultivar; oat plants of the cultivar 'Taura' are more competitive than of the cultivar 'Brava'; the impact of the gibberellin inhibitor trinexapac-ethyl on the weed-crop interaction is dependent on the oat cultivar; on plants from the oat cultivar 
'Brava', the gibberellin inhibitor can prevent yield losses due to ryegrass competition (up to 21 plants $\mathrm{m}^{-2}$ ).

\section{Acknowledgements}

The authors appreciate the research grants from National Council for Scientific and Technological Development (CNPq), the Brazilian Coordination for the Improvement of Higher Education Personnel (CAPES), the Federal University of Rio Grande do Sul. The authors declare no conflict of interest.

\section{Literature Cited}

Almeida, M. L.; Mundstock, C. M. Oat tillering affected by light quality, in plants under competition. Ciência Rural, v.31, n.3, p.393-400, 2001. https://doi.org/10.1590/S0103-84782001000300005.

Borlaug, N. E. Sixty-two years of fighting hunger: personal recollections. Euphytica, v.157, n.3, p.287-297, 2007. https://doi. org/10.1007/s10681-007-9480-9.

Casal, J.J.; Smith, H. Persistent effects of changes in phytochrome status on internode growth in light-grown mustard: occurrence, kinectics and locus of perception. Planta, v.75, n.2, p.214-220, 1988. https://doi.org/10.1007/BF00392430.

Cousens, R.; O'neill, M. Density dependence of replacement series experiments. Oikos, v.66, n.2, p.347-352, 1993. https://doi. org/10.2307/3544824.

Gal, J.; Afifi, M.; Lee, E.; Lukens, L.; Swanton, C.J. Detection of Neighboring Weeds Alters Soybean Seedling Roots and Nodulation. Weed Science, v.63, n.4, p.888-900, 2015. https:// doi.org/10.1614/WS-D-15-00039.1.

Hassanali, A.; Herren, H.; Khazan, Z. R.; Pickett, J. A.; Woodcock, C. M. Integrated pest management: The push-pull approach for controlling insect pests and weeds of cereals, and its potential for other agricultural systems including animal husbandry. Philosophical Transactions of the Royal Society of London, v.363, n.1491, p.611-621, 2008. https://doi.org/10.1098/ rstb.2007.2173.

Hawerroth, M. C.; Silva, J. A. G.; Souza, C. A.; Oliveira, A. C.; Luche, H. S.; Zimmer, C. M.; Hawerroth, F. J.; Schiavo, J; Sponchiado, J. C. Redução do acamamento em aveia-branca com uso do regulador de crescimento etil-trinexapac. Pesquisa Agropecuária Brasileira, Brasília, v. 50, n. 2, p. 115-125, 2015. https://doi.org/10.1590/ S0100-204X2015000200003.

Hoffman, M. L.; Buhler, D. D. Utilizing sorghum as a functional model of crop-weed competition. I. establishing a competitive hierarchy. Weed Science, v.50, n.4, p.466-472, 2002. https://doi. org/10.1614/0043-1745(2002)050[0466:USAAFM]2.0.CO;2.

Hooksa, C. R. R. Using marigold (Tagetes spp.) as a cover crop to protect crops from plant-parasitic nematodes. Applied Soil Ecology, v.46, n.3, p.307-320, 2010. https://doi.org/10.1016/j. apsoil.2010.09.005.

Lamego, F. P.; Vidal, R. A.; Burgos, N. R. Competitiveness of ALS inhibitors resistant and susceptible biotypes of Greater Beggarticks (Bidens subalternans). Planta Daninha, v.29, n.1, p.457-464, 2011. https://doi.org/10.1590/S0100-83582011000200024.
Lancashire, P. D.; Bleiholder, H., Boom, V.; Langelüddeke, P.; Stauss, R.; Weber, E.; Witzenberger, A. An uniform decimal code for growth stages of crops and weeds. Annals of Applied Biology, v.119, n.1, p.561-601, 1991. https://doi.org/10.1111/j.1744-7348.1991. tb04895.x.

Lângaro, N. C.; Federizzi, L. C.; Oliveira, A. C.; Riede, C. R.; Almeida, J. L.; Fontaneli, R. S. Cultivares de aveia, qualidade de sementes e implantação da cultura. In: Lângaro, N. C.; Carvalho, I. Q. (Orgs.). Indicações técnicas para a cultura da cultura da aveia. Passo Fundo: Ed. Universidade de Passo Fundo, 2014. p.44-53.

Liebman, M.; Baraibar, B.; Buckley, Y.; Childs, D.; Christensen, S.; Cousens, R.; Eizenberg, H.; Heijting, S.; Loddo, D.; Merotto, A.; Renton, M.; Riemens, M. Ecologically sustainable weed management: How do we get from proof-of-concept to adoption? Ecological Applications, v.26, n.1, p.1352-1369, 2016. https://doi. org/10.1002/15-0995.

Lortie, C. J.; Callaway, R. M. Re-analysis of meta-analysis: support for the stress-gradient hypothesis. Journal of Ecology, v.94, n.1, p.716, 2016. https://doi.org/10.1111/j.1365-2745.2005.01066.x.

Lou, X. Y.; Li, X.; Li, A. L.; Li, A. X.; Pu, M. Y.; Shoaib, M.; Liu, D. C.; Sun, J. Z.; Zhang, A. M.; Yang, W. L. Molecular characterization of three gibberellin-insensitive DWARF2 homologous genes in common wheat. Plos One, v.11, n.1, p.1-19, 2016. https://doi. org/10.1371/journal.pone.0157642.

Mckenzie-Gopsill, A. G.; Lee, E.; Lukens, L.; Swanton, C. J. Rapid and early changes in morphology and gene expression in soya bean seedlings emerging in the presence of neighbouring weeds. Weed Research, v.56, n.1, p.267-273, 2016. https://doi.org/10.1111/ wre.12207.

Milach, S. C. K.; Rines, H. W.; Phillips, R. L. Plant height components and gibberellic acid response of oat dwarf lines. Crop Science, v.42, n.4, p.1147-1154, 2002. http://doi.org/10.2135/ cropsci2002.1147.

Portugal, J. M.; Vidal, R. A. Economic levels of weed injury on crops: concepts, definitions and calculation models. Planta Daninha, v.27, n.4, p.869-877, 2009. https://doi.org/10.1590/S010083582009000400026 .

Poveda, K.; Kessler, A. New synthesis: plant volatiles as functional cues in intercropping systems. Journal of Chemical Ecology, v.38, n.11, p.1341, 2012. http://doi.org/10.1007/s10886-012-0203-x.

Radosevich, S.R.; Holt, J.S.; Ghersa, C.M. Ecology of weeds and invasive plants: relationship to agriculture and natural resource management. 3.ed. New York: John Wiley \& Sons, 2007. 454p.

Rigoli, R. P.; Agostinetto, D.; Vaz da Silva, J. M. B.; Fontana, L. C.; Vargas, L. V. Competitive potential of wheat cultivars as affected by emergence time. Planta Daninha, v.27, n.1, p.41-47, 2009. https://doi.org/10.1590/S0100-83582009000100007.

Schaedler, C. E.; Fleck, N. G.; Agostinetto, D.; Rigoli, R. P.; Dal Magro, T.; Tironi, S. P. Use and relative contributions of at genotypes and management practices to crop competitivity against concurrent plants. Planta Daninha, v.27, p.957-965, 2009. https://doi. org/10.1590/S0100-83582009000500009.

Trezzi, M. M.; Balbinot Jr, A. A.; Benin, G. I.; Debastiani, F.; Patel, F.; Miotto, E. Competitive ability of soybean cultivars with horseweed (Conyza bonariensis). Planta Daninha, v.31, n.3, p.543-550, 2013. https://doi.org/10.1590/S0100-83582013000300006. 
Vidal, R. A.; Trezzi, M. M.; Kozlowski, L. A.; Prates, M. V. B.; Cieslik, L. F.; Merotto, A. Initialism as a mechanism of weed interference: can a crop plant be blinded? Planta Daninha, v.30, n.3, p.469-475, 2012. https://doi.org/10.1590/S0100-83582012000300002.

Wanic, M.; Jastrzębska, M.; Kostrzewska, M. K.; Treder, K. Competition between spring barley (Hordeum vulgare L.) and italian ryegrass (Lolium multiflorum Lam.) under different water supply conditions. Acta Agrobotanica, v.66, n.3, p.73-80, 2013. http://doi.org/10.5586/aa.2013.040.

Weiner, J.; Andersen, S. B.; Wille, W. K. M.; Griepentrog, H. W.; Olsen, J. M. Evolutionary Agroecology: the potential for cooperative, high density, weed-suppressing cereals. Evolutionary Applications, v.3, n.1, p.473479, 2010. https://doi.org/10.1111/j.1752-4571.2010.00144.x.
Weinig, C.; Delph, F. F. Phenotypic plasticity early in life constrains developmental responses later. Evolution, v.55, n.5, p.930-936, 2001. https://doi.org/10.1111/j.0014-3820.2001.tb00610.x.

Wit, M.; Galvão, V. C.; Fankhauser, C. Light-mediated hormonal regulation of plant growth and development. Annual Review Plant Biology, v.67, n.1, p.513-537, 2016. https://doi.org/10.1146/ annurev-arplant-043015-112252.

Worthington, M. S.; Reberg-Horton, C.; Brown-Guedira, G.; Murphy, J. P. Morphological traits associated with weed-suppressive ability of winter wheat against italian ryegrass. Crop Science, v.55, n.1 p.50-56, 2015. http://doi.org/10.2135/cropsci2014.02.0149. 